Ebert, T.A. (2021). Problems and puzzles in echinoderm

demography. Revista de Biología Tropical, 69(S1),

1-13. DOI 10.15517/rbt.v69iSuppl.1.46318

DOI 10.15517/rbt.v69iSuppl.1.46318

\title{
Problems and puzzles in echinoderm demography
}

Thomas A. Ebert ${ }^{1 *}$

1. Department of Integrative Biology, Oregon State University, Corvallis, OR 97331, USA; ebertt@science.oregonstate.edu (*Correspondence).

Received 11-III-2020. C Corrected 24-VII-2021. Accepted 24-VII-2020.

\begin{abstract}
Introduction: There are problems and puzzles in understanding reproduction, growth and mortality in echinoderm life cycles. Objective: Explore problems and puzzles in life cycles that are important and challenging. Methods: The literature is used to elucidate problems associated with all life stages. Results: Sources of larvae that settle at a site are explored using oceanographic modelling and genetic methods. There are few studies that have estimated larval mortality in the plankton under field conditions and results differ from experimental results or patterns of settlement. In a small number of studies, mortality rate of newly settled larvae appears to change rapidly as individuals grow. There are problems measuring size, and measurement bias that interferes with many tagging methods used to estimate growth. There also are problems with the use of natural growth lines and commonly used software to estimate both growth and mortality from size-frequency data. An interesting puzzle is that echinoderms may show negative senescence with mortality rate decreasing with size. There is a problem in fertilization success based on density so there should not be rare species where sexes are separate with free spawning of gametes yet there seem to be rare echinoderms. Conclusions: All parts of echinoderm life cycles provide problems and puzzles that are important and challenging.
\end{abstract}

Key words: echinoderm; life-cycle; plankton; connectivity; growth, mortality; reproduction.

The following review explores problems and puzzles in the demography of echinoderms in the context of a complete life cycle for species that have planktonic larvae (Fig. 1). This is not intended to be an exhaustive review of literature but rather to show areas of echinoderm biology that are important and require attention and creative approaches. Some echinoderm groups have limited number of publications on particular aspects of life cycles and echinoids by far have the most detailed studies. In part, this is due to their importance both as grazers in near-shore environments and in fisheries. Holothurians also have important fisheries but are very difficult to study because size is difficult to measure and they lack hard parts with natural growth lines. Asteroids also are difficult to study and in general have limited commercial importance other than as pests or as the souvenir trade. Ophiuroids in some habitats have natural lines that can be used to estimate growth but because they lack any commercial value have not benefited from many detailed studies of all parts of life cycles for single species. Finally, crinoids have nearly no detailed studies of their life cycles.

Linkage of sources and sinks: Recognition of linking sources of larvae with sites of settlement is not new (e.g. Thorson, 1961) 


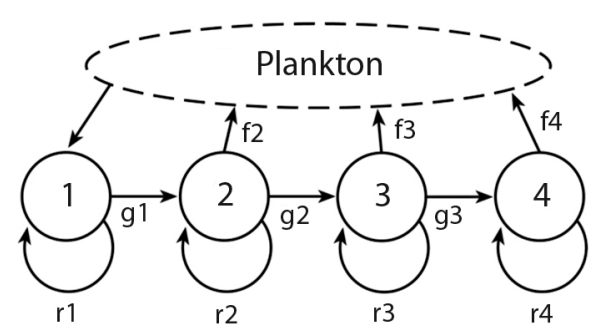

Fig. 1. Life-cycle graph with uncoupled reproduction (source) and settlement (sink) with four size classes; all arrows have a time constant of one year so fx values include gamete production, survival in the plankton, and postsettlement processes to an age of one year when individuals are in size-class 1; gx values are probabilities of growth to the next size class multiplied by the survival probability; rx values are the probabilities of not transferring to the next size class multiplied by the survival probability.

but the problem is how to determine the links between sources and sinks and estimate probabilities (Fig. 2). The general framework for such discussions is connectivity (Wing, Gibbs, \& Lamare, 2003; Cowen, Gawarkiewicz, Pineda, Thorrold, \& Werner, 2007).

Ocean currents: Modelling ocean currents can provide a framework for study and a means of generating hypotheses that need to be tested (Pineda, Hare, \& Sponaugle, 2007). An example of this approach is for the echinoid Loxechinus albus (Blanco, Ospina-Álvarez, Navarrete, \& Fernández, 2019). The simulation presented by these authors used oceanographic data along the coast of Chile together with a reasonable estimate of larval development time for L. albus, 20 days. The simulation started with establishing blocks along the coast and seeding these with passive particles and examining the distribution of particles after a simulation run of 20 days. The pattern of particles provides reasonable hypotheses for testing the connectivity of $L$. albus at sites along the coast. How one does this is a major problem.

Geochemical tags: Natural geochemical tags have been used for a variety of species to indicate sources of larvae (e. g. Thorrold et al., 2002; Levin, 2006; White, Standish, Thorrold,

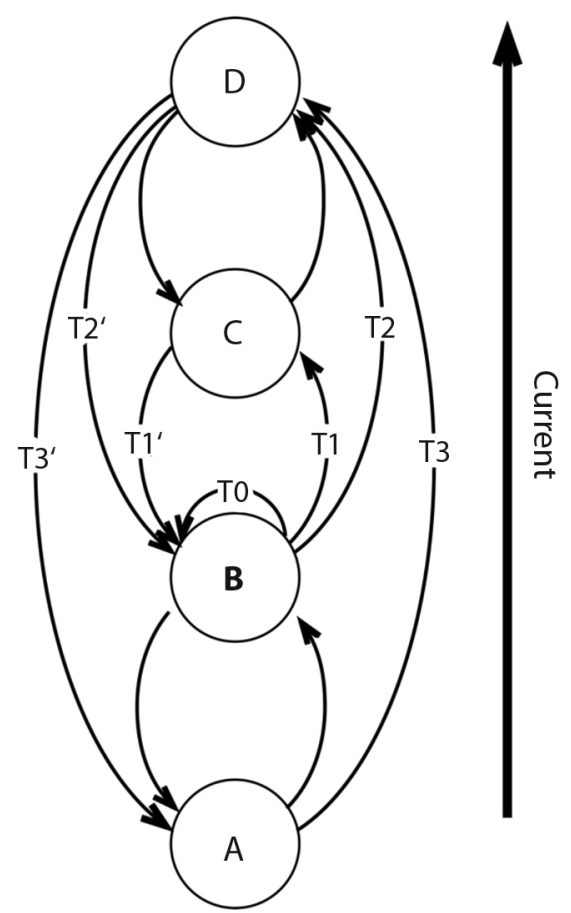

Fig. 2. Four locations (A, B, C, D) showing possible transfer probabilities, $\mathrm{Tx}$, in a directional current that include numbers of gametes produced at a site multiplied by the probability of successful transfer to the same or other site, the connectivity of sites.

\& Warner, 2008). Use of elemental signatures in calcareous structures to trace of the transport of echinoderm larvae, however, may have limited use. Holothurian and asteroid larvae lack calcareous structures. Ophiuroids lose larval spicules during metamorphosis. Echinoids, however, retain remnants of larval spicules at metamorphosis (Gordon, 1926; Emlet, 1985) but these are very small and may be too small for analysis. This has not been explored. A related issue is whether there are elemental differences in echinoid skeletons along a coastline of interest that could be used to identify source areas for larvae. This is a question that could be addressed with current technology using samples from spines that show regenerating tips and internal regions separated by growth interruption lines. Spine tips regenerate rapidly and so represent close to point-samples in time 
(i.e. Ebert, 1967; Heatfield, 1971; Gorzelak, Stolarski, Dubois, Kopp, \& Meibom, 2011). Analysis of regenerating spine tips would be a rapid way of discovering whether local elemental signatures might be useful in identifying sources of echinoid larvae that settle.

Genetic markers: Genetic measures of connectivity (Hedgecock, Barber, \& Edmands, 2007) provide large-scale patterns that show accumulation of differences over many years. All echinoderm classes are represented in such studies: crinoids (Hemery et al., 2012), asteroids (Marcus, 1977; Keever et al., 2009; Yasuda et al., 2012), ophiuroids (Cho \& Shank, 2010), holothuroids (Uthicke \& Benzie, 2003), and echinoids (Watts, Johnson, \& Black, 1990; Miller, Supernault, Li, \& Withler, 2006; Casilagan, Juinio-Meñez, \& Crandall, 2013).

Connectivity on a finer scale to indicate sources and sinks is less common and may indicate the nature of the problem of addressing the source or sources of larvae that settle at a site. There are studies of the echinoid Strongylocentrotus purpuratus in southern California and Mexico that explore genetic patterns. Edmands, Moberg, and Burton (1996) using allozymes found differentiation over short distances could be as great as those seen at larger scales. A lack of genetic pattern in recruits of $S$. purpuratus was reported by Flowers, Schroeter, and Burton (2002) with no indication of reproductive sweepstakes in the sense that for any year some females provided more offspring than others. Settlers on brushes with ages of one or two weeks appeared to have resulted from many females. Changes in the shape of the coastline appeared not to generate patterns at least for species with long generation times so sufficient unusual settlement events can obscure differences (e.g. Olivares-Bañuelos, EnríquezParedes, Ladah, \& De La Rosa-Vélez, 2008).

Major coastal features can create patterns for some species and indicate that sources and sinks are within particular subregions of overall distribution. The echinoid Arbacia stellata was studied along the central coast of Baja California, Mexico, and around up into the middle of the Gulf of California (OlguínEspinoza, 2003) using allozyme analysis of ten polymorphic loci. Breaks were evident associated with Punta Eugenia and the tip of Baja California (Fig. 3). Further differentiation was evident along the east coast of the peninsula to

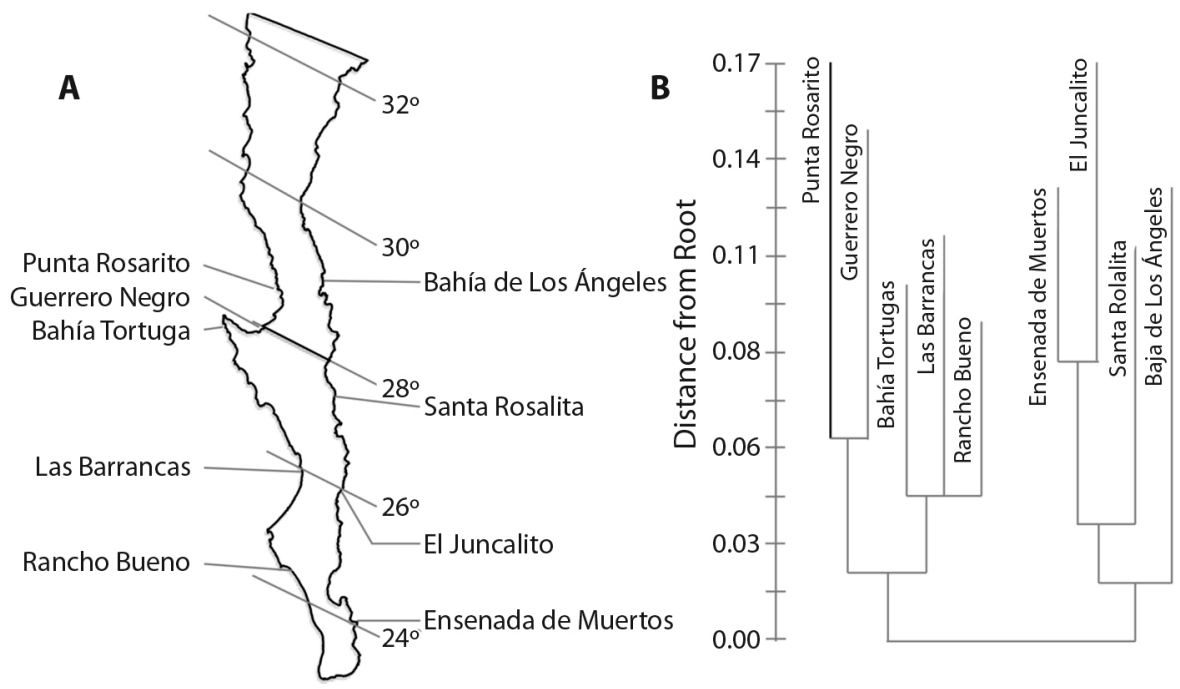

Fig. 3. Connectivity of Arbacia stellata around Baja California, Mexico based on analysis of ten polymorphic loci. A. locations of intertidal study sites. B. genetic relationships among populations based on a distance Wagner tree rooted at the midpoint of the longest path; there are breaks associated with coastline features: Punta Eugenia and Cabo San Lucas; distance is important within the Gulf of California (after Olguín-Espinoza, 2003). 
Bahía de los Angeles. The differentiation may indicate restrictions to gene flow and so aid in understanding the connectivity of sources and sinks. Generation times may be very short for Arbacia species based on rapid growth and size structure (Olguín-Espinoza, 2003; Barrera, 2018) and short generation times would promote differentiation.

The problem of connectivity using genetic methods is difficult and made more so with echinoderm species that have mixed reproduction methods such the holothurian Stichopus chloronotus (Uthicke, Benzie, \& Ballment, 1999; Soliman, Takama, Fernandez-Silva, \& Reimer, 2016; Pirog et al., 2017).

Understanding the connectivity of echinoderms and other marine species becomes very important in the development of marine reserves and fishing regulations. If larvae are mixed from many sites as indicated by Flowers et al. (2003) importance for maintaining a species may depend very little on particular marine reserves and more on the overall stock density. On the other hand, species that have short generation times and high dispersal may benefit from both site selection and size of reserves. Connecting populations may continue to be best done using a combination of genetics and oceanographic models as suggested by Hedgecock et al. (2007) with a focus on following cohorts, which is not an easy problem to solve.

Mortality in the plankton: A major problem in the plankton studies is the estimation of mortality. It is generally agreed that loss in the plankton must be very high given the large number of eggs produced per female and the number of new individuals age-one that appear in benthic populations. But what are the mortality values? Two studies in particular have estimates of planktonic mortality rates under field conditions. Rumrill (1987) sampled plankton in an arm of Barkley Sound, Vancouver Island, British Columbia, Canada, and estimated densities of early developmental stages of the echinoids Strongylocentrotus droebachiensis and $S$. purpuratus on a daily basis during spawning episodes. The rate of decline from peak density was used to estimate daily mortality. A similar approach was used by Lamare and Barker (1999) to estimate daily mortality of the echinoid Evechinus chloroticus larvae in Doubtful Sound, South Island, New Zealand.

An experimental approach to larval mortality focused on just the role of predation (Johnson \& Shanks, 2003). In experimental chambers, daily losses due to predation could be very low and approaching zero. A different approach to estimating larval mortality is given by analyzing the consequences of larval cloning where persistence in the plankton during development would require low rates of mortality (Ebert \& Janies, 2020). Comparison of different estimates (Table 1) shows the wide divergence of estimates.

An additional complication to survival in the plankton is provided by settlement of $S$. purpuratus larvae on brushes in southern California. Gonads increase in mass during summer and fall with a drop indicating spawning (e.g. Basch \& Tegner, 2007). Ocean circulation is complex south of Point Conception. The Channel Islands provide conditions favorable to formation of eddies and gyres in the Santa Barbara Channel (e.g. Harms \& Winant, 1998) that may hold larvae near shore and increase the settlement season. Larval retention in the Santa Barbara Channel may be the explanation for the striking difference between settlement at Scripps Institution of Oceanography and Gaviota (Fig. 4). A short period of spawning and a long period of settlement means that survival in the plankton may be much better than indicated by the work of Rumrill (1987) and Lamare and Barker (1999). We still have a very poor understanding of survival and sources of mortality in the plankton.

Post-settlement growth and mortality: There are few studies of post-settlement growth and survival of echinoderms under field conditions. Rowley (1990) followed cohorts of newly-settled $S$. purpuratus at Naples Reef near Santa Barbara, California. Based on his Figure 7, mortality, $\mathrm{M} \mathrm{day}^{-1}$, was 0.034 in barrens and 0.060 in a kelp bed. Growth between 
TABLE 1

Estimates of mortality (M) of echinoderm larvae in the plankton; Johnson and Shanks (2003) measured losses in replicated chambers due to predation over one-day periods; Ebert and Janies (2020) are calculations based on the assumption that a population of larvae could be sustained in the plankton by budding only with development time of 25 days

\begin{tabular}{llccl}
\multicolumn{1}{c}{ Species } & \multicolumn{1}{c}{ Location } & days & M day-1 & \multicolumn{1}{c}{ Reference } \\
Evechinus chloroticus & Doubtful Sound, South Is., New Zealand & 14 & 0.171 & Lamare \& Barker, 1999 \\
Evechinus chloroticus & Doubtful Sound, South Is., New Zealand & 17 & 0.242 & Lamare \& Barker, 1999 \\
Evechinus chloroticus & Doubtful Sound, South Is., New Zealand & 30 & 0.209 & Lamare \& Barker, 1999 \\
Evechinus chloroticus & Doubtful Sound, South Is., New Zealand & 10 & 1 & Lamare \& Barker, 1999 \\
Strongylocentrotus droebachiensis & Barkley Sound, Vancouver Is., Canada & 13 & 0.156 & Rumrill, 1987, 1990 \\
Strongylocentrotus droebachiensis & Barkley Sound, Vancouver Is., Canada & 17 & 0.063 & Rumrill, 1987, 1990 \\
Strongylocentrotus purpuratus & Barkley Sound, Vancouver Is., Canada & 11 & 0.266 & Rumrill, 1987, 1990 \\
Dendraster excentricus & Coos Bay, OR, \& Friday Harbor, WA, USA & 1 & 0.001 & Johnson \& Shanks, 2003 \\
Oreaster sp. with one bud & Gulf Stream-Florida Current & 25 & 0.028 & Ebert \& Janies, 2020 \\
Oreaster sp. with two buds & Gulf Stream-Florida Current & 25 & 0.044 & Ebert \& Janies, 2020 \\
\hline
\end{tabular}

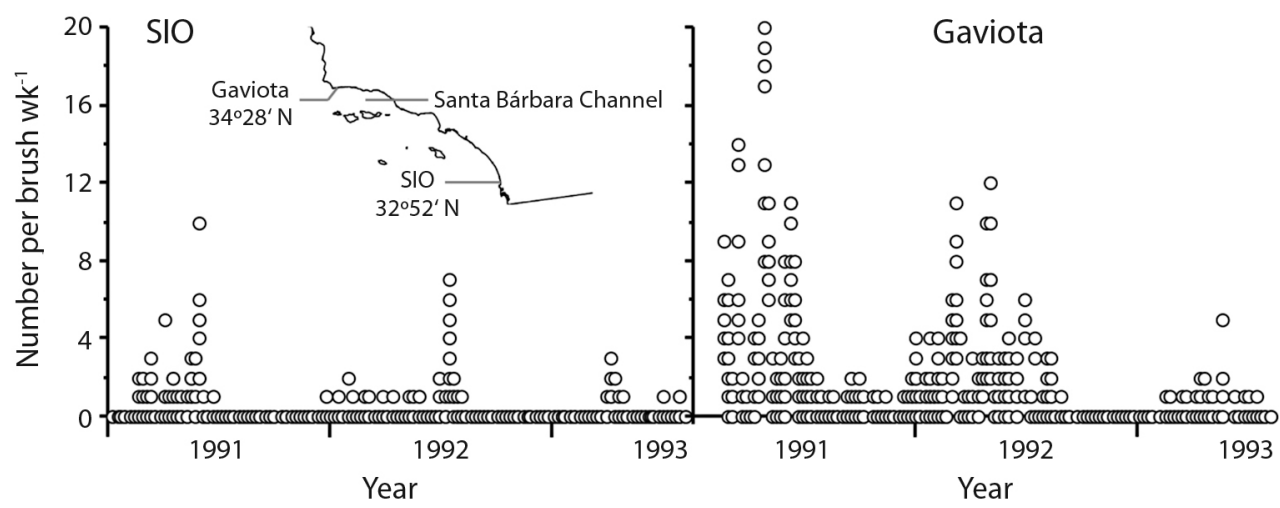

Fig. 4. Differences between settlement per week (wk) of Strongylocentrotus purpuratus on scrub brushes at Scripps Institution of Oceanography (SIO) and Gaviota; Gaviota is in the Santa Barbara Channel where gyres sometime form (Harms \& Winant, 1998); original data from Ebert, Schroeter, Dixon, and Kalvass (1994).

habitat types also was different with early post-settlement growth faster on barrens for the first 50 days $\left(0.42 \mathrm{~mm} \mathrm{month}^{-1}\right.$ vs. 0.31 $\left.\mathrm{mm} \mathrm{month}^{-1}\right)$. After 50 days and sizes of 0.8 $1.2 \mathrm{~mm}$, feeding begins on pieces of algae and growth becomes much faster in the kelp bed so by the end of a year, age-one sea urchins feeding on algae had an estimated diameter of $1.7 \mathrm{~cm}$ whereas they attained only $0.36 \mathrm{~cm}$ living on the barrens area. Early mortality of the asteroid Acanthaster planci (Keesing, Halford, \& Hall, 2018) was estimated as 6.5 and $7.8 \%$ $\mathrm{d}^{-1}$ for 1.0 and $1.6 \mathrm{~mm}$ individuals, decreasing with size to $1.2 \% \mathrm{~d}^{-1}(2.7 \mathrm{~mm})$ and $0.45 \% \mathrm{~d}^{-1}$
(5.5 mm). The rapid changes in mortality with small increases in size differ from the more constant rates observed by Rowley (1990) for $S$. purpuratus. Studies of newly settled echinoderms are rare and have emphasized the role of small predators and so differences between the work on Strongylocentrotus and Acanthaster may reflect different predators or other factors. Clearly, more field studies of newly-settled echinoderms are needed.

Growth and survival: Past early growth and survival there are general problems of estimating growth, which lead to problems 
of estimating mortality. The first problem is measuring size. For some echinoderms the problem is obvious: holothurians are very difficult to measure. Both length and weight are subject to changes in size of individuals in response to being handled or their resting state. For example, Herrero-Pérezrul, Reyes-Bonilla, García-Domínguez and Cintra-Buenrostro (1999) working with the holothurian Isostichopus fuscus measured length underwater with a tape to avoid disturbing the sea cucumbers and then brought individuals to the surface to determine weight. They found a positive allometric relationship between length and weight but with a wide spread of data points so individuals that were $20 \mathrm{~cm}$ long weighed between 100 and $500 \mathrm{~g}$. Isostichopus fuscus that measured $30 \mathrm{~cm}$ long weighed between 300 and $800 \mathrm{~g}$. Measuring size of holothurians is difficult and it is not clear whether length is a more consistent measure than weight or whether contracted length is better than relaxed length. Inter-radial ossicle width is related to contracted body length in Holothuria (Halodeima) atra (Ebert, 2010). An inter-radial ossicle $4 \mathrm{~mm}$ wide can be associated with a length of 6 to $22 \mathrm{~cm}$. A further complication of the relationship is due to asexual reproduction by fission that will result in large ossicles in short sea cucumbers or very small ossicles in the regenerating posterior segment.

Although measuring sea urchins seems simple, the presence of spines and associated tubercles can lead to size-specific biases. For example, red sea urchins, Mesocentrotus franciscanus, from San Nicolas Island, California, were measured live and individuals were again measured following cleaning in $5 \%$ sodium hypochlorite bleach. The difference between cleaned and live plotted against diameter measured live (Fig. 5) shows that there is substantial measurement bias so a sea urchin that was measured with a diameter of $9 \mathrm{~cm}$, when measured following cleaning may have been only $8.3 \mathrm{~cm}$ but also may have been very close to 8.3 $\mathrm{cm}$ when measured wet. The important point is that there is bias in measurement and the level of bias can exceed the amount to growth over a period of study such as a year or longer. The implication is that any tagging method that uses external tags such as Floy or dart tags or internal tags like PIT or coded wire will produce flawed growth curves that will tend to have an estimated maximum size much smaller than actual growth.

Natural growth lines have been used to estimate age for many echinoderm species: ophiuroids (Gage, 1990; Dahm, 1996; Quiroga \& Sellanes, 2009), echinoids (Deutler, 1926; Moore, 1935; Nichols, Sime, \& Bishop, 1985; Cabanac \& Himmelman, 1996; Ouréns, Flores, Fernández, \& Freire, 2013), and holothuroids (Sun, Hamel, Gianasi, \& Mercier, 2019). There are several problems with using natural lines. The first is the dependence on worker variation in what lines are counted. For example, two studies of the sand dollar Echinarachnius parma (Cocanour, 1969; Cabanac

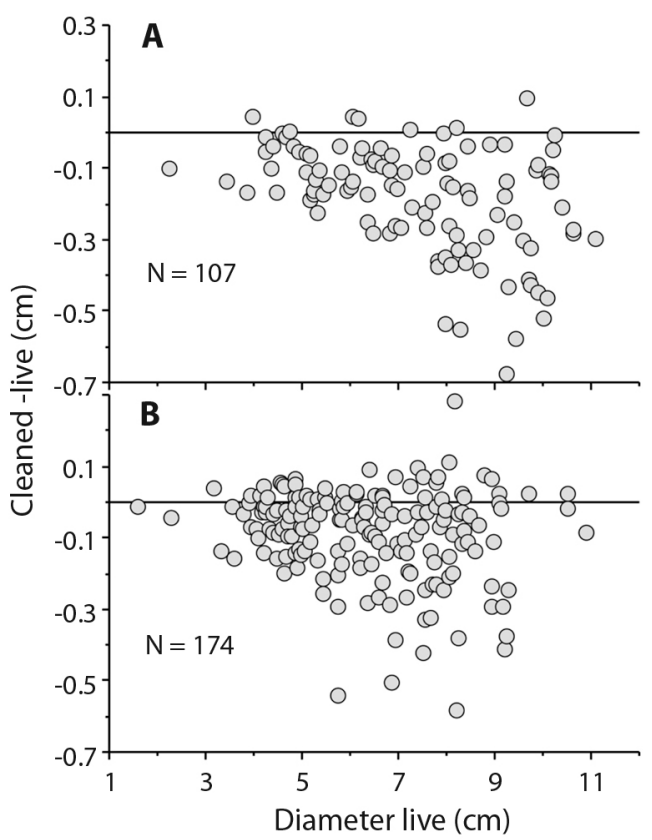

Fig 5. Bias in measurement of Mesocentrotus franciscanus collected in 1990 at San Nicolas Island, California (Ebert \& Russell, 1992); sea urchins were measured live (wet) and again following cleaning with sodium hypochlorite that removes spines. A. measurements by M.P. Russell. B. measurements by T.A. Ebert; the trend is there is a greater probability that large sea urchins will have greater bias in wet measurements. 


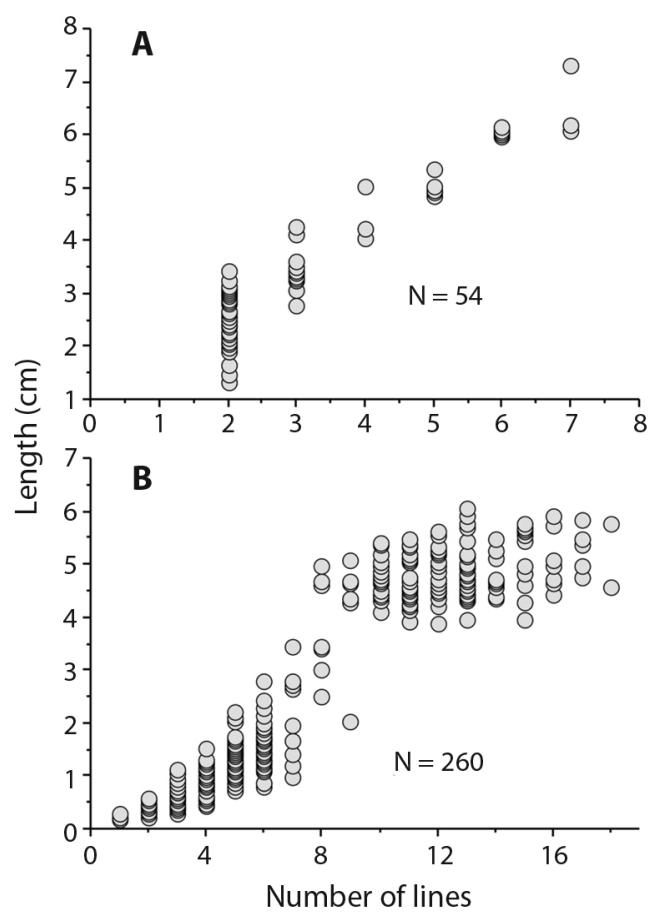

Fig. 6. Number of growth lines counted in the sand dollar, Echinarachnius parma, showing the difference between counts by different workers. A. Cocanour (1969). B. Cabanac and Himmelman (1996); the consequence of differences results in different estimates of size at age and different growth models that would be appropriate.

\& Himmelman, 1996) show differences in the estimates of age and growth (Fig. 6) that are the result of what lines are classed as annual. A second problem is found in old individuals that are growing so slowly that annual lines cannot be resolved. This problem usually is not addressed and the result is that age of large individuals is seriously underestimated and hence a growth model that is selected may be flawed and estimates of mortality underestimated. Some authors, however, have recognized and commented on the problem (Brey, Pearse, Basch, McClintock, \& Slattery, 1995; Shelton, Woodby, Hebert, \& Witman, 2006). Validation of lines with tetracycline show clear support for annual growth of small and medium sized sea urchins but tetracycline lines can be so close to the edge of small ossicles of large individuals that they have been considered to be errors (Ouréns et al., 2013).

Mortality estimation: Estimating mortality is difficult and usually is done using a combination of growth and size. A general approach is to use a length-converted catch curve where growth parameters are used to change size-frequency into age-frequency. The decline in age-categories are used to estimate mortality. Common programs for doing this are FISAT II, ELEFAN in R, and TropFishR. These methods use the von Bertalanffy growth model and so have an asymptotic size, $\mathrm{S} \infty$, which has problems associated with estimation (Schwamborn, 2018). The problem can be illustrated using data from tagged Echinometra mathaei when the von Bertalanffy model is used. When von Bertalanffy growth parameters were estimated from tagging, asymptotic size was estimated to be at the mode of large sea urchins (Fig. 7). To estimate mortality, growth has to be known for individuals on the descending limb of the size-frequency distribution, which is not possible with the parameters determined using von Bertalanffy growth. A solution is to estimate a different maximum size and this is done using the Powell-Wetherall plot method (Powell, 1979; Wetherall, 1986). With a larger asymptotic size, a new value for the parameter $\mathrm{K}$ can be determined by drawing a line through the mean of the growth data, the dashed line in Figure 7. The new growth parameters can now be used to estimate annual mortality, M, using a length-converted catch curve. The estimate of $\mathrm{M}$ is $0.146 \mathrm{yr}-1$, which is the same, $0.145 \mathrm{yr}-1$, as determined using the Richards function and combining the size data from 1976 and 1977 (Ebert, 1982). These estimates are similar to the means of 1976 and 1977 estimated using means of size data and different growth models (Ebert, 2013): $0.136 \mathrm{yr}-1$ for von Bertalanffy and $0.141 \mathrm{yr}-1$ using the Tanaka model. The von Bertalanffy growth parameters derived using the Powell-Wetherall method are poor compared with the actual tagging data. The estimates of annual mortality, however, are not unreasonable. This is interesting and deserves 

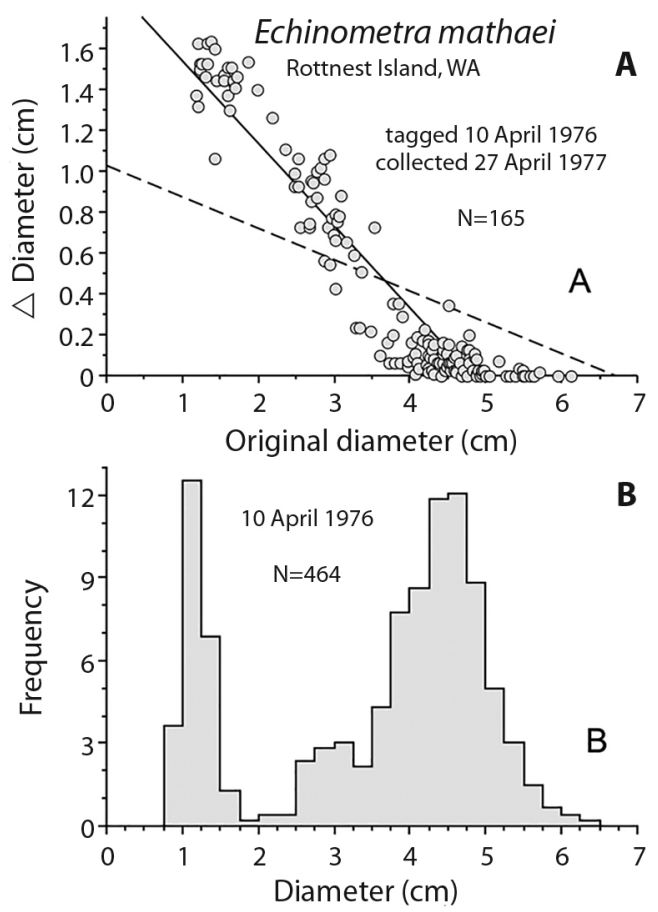

Fig. 7. A. A problem with the length-converted catch curve using the right limb of the size-frequency distribution when the von Bertalanffy growth model is used (solid line in $\mathbf{A}$ ); the original size at which growth is 0 is $\mathrm{D} \infty, 4.82 \mathrm{~cm}$ and the associated growth constant, $\mathrm{K}=0.52 \mathrm{yr}-1 ; \mathrm{D} \infty, 4.82 \mathrm{~cm}$ is at the mode of the size distribution, B. and so cannot be used to convert sizes to ages; dashed line in $\mathbf{A}$ is the result of estimating D $\infty$ by the Powell-Wetherall method, which gives $\mathrm{D} \infty, 6.69 \mathrm{~cm}$ and associated value of $\mathrm{K}=0.17 \mathrm{yr}-1$ so the sizes of the right limb can be converted into age classes.

additional exploration using different growth models with the length-converted catch curve.

Senescence: The model used to describe adult mortality, $\mathrm{M}$, is the simple decaying exponential:

$$
N_{t}=N_{0} e^{-M t}
$$

This equation is used because information is lacking to require a more complicated model that would include changes in mortality rate with age or size; $\mathrm{M}$ is a constant. A consequence of having a constant mortality rate regardless of age or size is that there is no senescence or negligible senescence (Finch, 1990). A question is whether echinoderms show changes in mortality with age or size and there is evidence that they do. Survival rate may actually improve rather than decline with age. Vaupel, Baudisch, Dölling, Roach, and Gampe (2004) coined the term negative senescence and proposed that candidates should have indeterminate growth, begin reproduction early in life and then continue to reproduce for as long as they live. Data for echinoderms to test the presence of these characteristics are few. Three sea urchin species have sufficient data that show changes in size-specific reproduction, growth, and mortality (Ebert, 2019). An example, S. purpuratus, shows indeterminate growth, increased reproductive output with size, and decreased mortality with size (Fig. 8). It is unknown how common this pattern might be for other echinoderms. Problems include demonstrating indeterminate growth, which requires using a method that can measure very small growth increments, which as indicated above probably must be done using chemical tagging of all sizes. Size-specific reproduction requires gonad changes for all sizes and analysis done with raw data rather than using restricted sizes. Changes in mortality can be estimated using the method of Van Sickle (1977) but there may be problems that need exploration such as how variance in size changes with time and how this might impact the estimate of mortality. Determining whether negative senescence is common in echinoderms is challenging.

Rarity and fertilization success: Can echinoderm species with separate sexes and a planktonic stage, also be rare? Collections at a location may contain species that are uncommon or rare but merely reflect local conditions such as shown by ophiuroids collected under intertidal rocks at False Point, La Jolla, California (Muscat, 1975). Not all of the species in Table 2 have planktonic larvae. Both, the ophiuroids Ophioplocus esmarki and Amphipholis squamata are brooders and Ophiactis simplex has mixed reproduction that includes fission. Also, the intertidal under rock habitat is not preferred by some species. For example, 

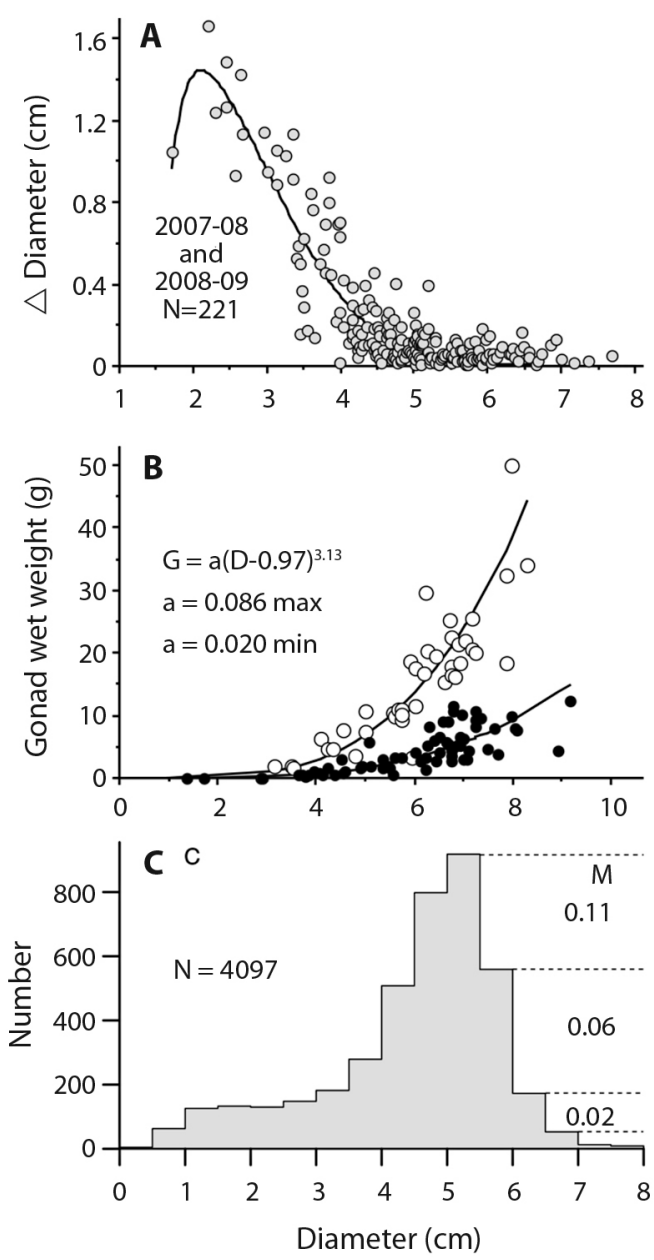

Fig. 8. Strongylocentrotus purpuratus growth (A. Sunset Bay, Oregon); maximum and minimum gonad sizes (B. Sunset Bay and Gregory Point Oregon); size structure and annual size-specific mortality rate, M, (C. Sunset Bay 1964-2009); S. purpuratus has indeterminate growth, no reduction of game production with size (age) and shows decreasing mortality, $\mathrm{M}$ yr-1, with size; these are attributes of negative senescence.

Ophiothrix (Ophiothrix) spiculata is very abundant subtidally and $O$. simplex is abundant in sponges so being uncommon or rare can just result from sampling in marginal habitats. What remains is Ophiocnida hispida. Is it rare or just not sampled in a preferred habitat? Little is known about $O$. hispida. Austin \& Hadfield (1980) simply say that it occurs in the intertidal of southern California. It is present farther
TABLE 2

Ophiuroids under intertidal rocks. False Point, La Jolla, California, 1973-74; area $=1750$ m2 (Muscat, 1975)

\begin{tabular}{lc}
\multicolumn{1}{c}{ Species } & Total \\
Ophionereis annulata & 2513 \\
Ophioplocus esmarki & 2401 \\
Amphipholis squamata & 618 \\
Ophiothrix (Ophiothrix) rudis & 545 \\
Ophioderma panamense & 209 \\
Ophiopteris papillosa & 101 \\
Ophiothrix (Ophiothrix) spiculata & 61 \\
Ophiactis simplex & 8 \\
Ophiocnida hispida & 2 \\
\hline
\end{tabular}

south (Granja-Fernández et al., 2014) but few specimens were collected in survey. Little is known about the biology of $O$. hispida but it probably has separate sexes with free spawning of gametes. These are traits that Vermeij \& Grosberg (2018) argue are not compatible with persistence because of problems of fertilization when individuals are widely spaced.

The newly discovered asteroid Oreaster (Janies et al., 2019) appears to be rare as a benthic stage but it is possible that population maintenance is through budding in the plankton as indicated above. Rarity is a problem and a usual conjecture is that the species may be much more common in some place that has yet to be discovered. Problems with fertilization can be related to rates of adult mortality. If mortality rates are low then low rates of fertilization can be compensated for by having many spawning events over a lifetime. Most years may be unsuccessful but occasionally successful fertilization occurs. Mortality rates are the result of mechanisms that promote life and hence under forces of selection. Problems with fertilization close the life-cycle (Fig. 1) started at the beginning of this manuscript.

Conclusion: Work is needed for all echinoderm groups to resolve problems and puzzles to understand growth and survival at all life stages from connectivity across geographic regions through processes in the plankton, early post-settlement growth and mortality, 
problems with measuring size and determining patterns of growth and mortality, changes in mortality with age or size that may indicate negative senescence, and problems of rarity. All of these problems are inter-related in the total life cycle.

Ethical statement: authors declare that they all agree with this publication and made significant contributions; that there is no conflict of interest of any kind; and that we followed all pertinent ethical and legal procedures and requirements. All financial sources are fully and clearly stated in the acknowledgements section. A signed document has been filed in the journal archives.

\section{ACKNOWLEDGMENTS}

I thank the organizing committee of the $4^{\text {th }}$ Latin American Echinoderm Conference and in particular Dinorah Herrero for inviting me to La Paz to give the lecture on which this paper is based. Work with settlement in southern California was with S. Schroeter and J. Dixon. Work with growth of S. purpuratus in Oregon was with J.C. Hernández and S. Clemente. Portions of the work were supported by the US National Science Foundation, the Washington Department of Fish and Wildlife, the US Fish and Wildlife Service, Directors Sea Urchin Advisory Committee of the California Department of Fish and Game and personal funds.

\section{RESUMEN}

\section{Problemas y acertijos en la demografía de los equinodermos}

Introducción: Existen problemas y acertijos en la comprensión de la reproducción, el crecimiento y la mortalidad en los ciclos de vida de los equinodermos. Objetivo: Explorar los problemas y acertijos en los ciclos de vida que son importantes y desafiantes. Métodos: La literatura es usada para dilucidar los problemas asociados con todas las etapas de vida. Resultados: Las fuentes de larvas que se asientan en un sitio se exploran usando modelos oceanográficos y métodos genéticos. Existen pocos estudios que han estimado la mortalidad larval del plancton bajo condiciones de campo y los resultados difieren de los resultados experimentales o los patrones de asentamiento. En un número pequeño de estudios, la tasa de mortalidad de las larvas recién asentadas parece cambiar rápidamente a medida que los organismos crecen. Existen problemas para medir tamaños y el sesgo de medición interfiere con el uso de muchos métodos de marcado para estimar el crecimiento. También hay problemas con el uso de las líneas de crecimiento natural y con los programas comúnmente usados para estimar tanto el crecimiento como la mortalidad a partir de datos de frecuencia de tamaño. Un acertijo interesante es que los equinodermos pueden mostrar senescencia negativa con una tasa de mortalidad que disminuye con el tamaño. Existe un problema con el éxito de la fertilización basado en la densidad, por lo que no debería haber especies raras cuando los sexos están separados y existe un desove libre de gametos, sin embargo, parece haber equinodermos raros. Conclusiones: Todas las partes de los ciclos de vida de los equinodermos proveen problemas y acertijos que son importantes y desafiantes.

Palabras clave: equinodermos; ciclo de vida; plancton; conectividad; crecimiento; mortalidad; reproducción.

\section{REFERENCES}

Austin, W.C., \& Hadfield, M.G. (1980). Ophiuroidea: The brittle stars. In R.H. Morris, D.P. Abbott, \& E.C. Haderlie (Eds.), Intertidal Invertebrates of California (pp. 146-159). California: Stanford University Press.

Barrera, A.M. (2018). Estimación del crecimiento del erizo de mar Arbacia lixula (Master's thesis). Universidad de La Laguna, Tenerife, Canary Islands, Spain.

Basch, L.V., \& Tegner, M.J. (2007). Reproductive responses of purple sea urchin (Strongylocentrotus purpuratus) populations to environmental conditions across a coastal depth gradient. Bulletin of Marine Science, 81(2), 255-282.

Blanco, M., Ospina-Álvarez, A., Navarrete, S.A., \& Fernández, M. (2019). Influence of larval traits on dispersal and connectivity patterns of two exploited marine invertebrates in central Chile. Marine Ecology Progress Series, 612, 43-64.

Brey, T., Pearse, J., Basch, L., McClintock, J., \& Slattery, M. (1995). Growth and production of Sterechinus neumayeri (Echinoidea: Echinodermata) in McMurdo Sound, Antarctica. Marine Biology, 124, 279-292.

Cabanac, A., \& Himmelman, J.H. (1996). Population structure of the sand dollar Echinarachnius parma in the subtidal zone of the northern Gulf of St. Lawrence, eastern Canada. Canadian Journal of Zoology, 74(4), 698-709.

Casilagan, I.L.N., Juinio-Meñez, M.A., \& Crandall, E.D. (2013). Genetic diversity, population structure, and demographic history of exploited sea urchin 
populations (Tripneustes gratilla) in the Philippines. Journal of Experimental Marine Biology and Ecology, 449, 284-293.

Cho, W., \& Shank, T.M. (2010). Incongruent patterns of genetic connectivity among four ophiuroid species with differing coral host specificity on North Atlantic seamounts. Marine Ecology, 31(S1), 121-143.

Cocanour, B.A. (1969). Growth and reproduction of the sand dollar, Echinarachnius parma (Echinodermata: Echinoidea) (Doctoral thesis). University of Maine, Orono, USA.

Cowen, R.K., Gawarkiewicz, G., Pineda, J., Thorrold, S.R., \& Werner, F.E. (2007). Population connectivity in marine systems: An overview. Oceanography, 20(3), 14-21.

Dahm, C. (1996). Ökologie und Populationsdynamik antarktischer Ophiuroiden (Echinodermata). Berichte zur Polarforschung, 194, 1-289.

Deutler, F. (1926). Über das Wachstum des Seeigelskeletts. Zoologische Jahrbücher. Abteilung für Anatomie und Ontogenie der Tiere, 48, 119-200.

Ebert, T.A. (1967). Growth and repair of spines in the sea urchin Strongylocentrotus purpuratus (Stimpson). Biological Bulletin, 133, 141-149.

Ebert, T.A. (1982). Longevity, life history, and relative body wall size in sea urchins. Ecological Monographs, 52, 353-394.

Ebert, T.A. (2010). Dynamics of Holothuria atra at Enewetak Atoll, Republic of the Marshall Islands, based on tetracycline tagging. In L.G.Harris, S.A. Böttger, C.W. Walker, \& M.P. Lesser (Eds.), Echinoderms: Durham (pp. 609-614). The Netherlands: CRC Press/ Balkema.

Ebert, T.A. (2013). Use of diverse growth models to estimate annual survival from mean size in a sample: Examples using sea urchins. Cahiers de Biologie Marine, 54, 605-613.

Ebert, T.A. (2019). Negative senescence in sea urchins. Experimental Gerontology, 122, 92-98.

Ebert, T.A., \& Russell, M.P. (1992). Growth and mortality estimates for red sea urchin, Strongylocentrotus franciscanus, from San Nicolas Island, California. Marine Ecology Progress Series, 81, 31-41.

Ebert, T.A., Schroeter, S.C., Dixon, J.D., \& P. Kalvass. P. (1994). Settlement patterns of red and purple sea urchins (Strongylocentrotus franciscanus and S. purpuratus) in California, USA. Marine Ecology Progress Series, 111, 41-52.

Ebert, T.A., \& Janies, D.A. (2020). Modeling the life cycle of echinoderm larvae clones. Bulletin of Marine Science, 96(1), 221-228.
Edmands, S., Moberg, P.E., \& Burton, R.S. (1996). Allozyme and mitochondrial DNA evidence of population subdivision in the purple sea urchin Strongylocentrotus purpuratus. Marine Biology, 126, 443-450.

Emlet, R.B. (1985). Crystal axes in recent and fossil adult Echinoids indicate trophic mode in larval development. Science, 230, 937-940.

Finch, C. (1990). Longevity, Senescence, and the Genome. Illinois: University of Chicago Press.

Flowers, J.M., Schroeter, S.C., \& Burton, R.S. (2002). The recruitment sweepstakes has many winners: genetic evidence from the sea urchin Strongylocentrotus purpuratus. Evolution, 56(7), 1445-1453.

Gage, J.D. (1990). Skeletal growth bands in brittle stars: microstructure and significance as age markers. Journal of the Marine Biological Association of the United Kingdom, 70(1), 209-224.

Gordon, I. (1926). The development of the calcareous test of Echinus miliaris. Philosophical Transactions of the Royal Society of London. Series B, 214, 259-312.

Gorzelak, P., Stolarski, J., Dubois, P. Kopp, C., \& Meibom, A. (2011). 26Mg labeling of the sea urchin regenerating spine: Insights into echinoderm biomineralization process. Journal of Structural Biology, 176(1), 119-126.

Granja-Fernández, R., Herrero-Pérezrul, M.D., LópezPérez, R.A., Hernández, L., Rodríguez-Zaragoza, F.A., Jones, R.W., \& Pineda-López, R. (2014). Ophiuroidea (Echinodermata) from coral reefs in the Mexican Pacific. ZooKeys, 406, 101-145.

Harms, S., \& Winant, C.D. (1998). Characteristic patterns of the circulation in the Santa Barbara Channel. Journal of Geophysical Research, 103(C2), 3041-3065.

Heatfield, B.M. (1971). Growth of the calcareous skeleton during regeneration of spines of the Sea Urchin, Strongylocentrotus purpuratus (Stimpson): A light and scanning electron microscopic study. Journal of Morphology, 134(1), 57-89.

Hedgecock, D., Barber, P.H., \& Edmands, S. (2007). Genetic approaches to measuring connectivity. Oceanography, 20(3), 70-79.

Hemery, L.G., Eléaume, M., Roussel, V., Améziane, N., Gallut, C., Steinke, D., Cruaud, C., Couloux, A., \& Wilson, N.G. (2012). Comprehensive sampling reveals circumpolarity and sympatry in seven mitochondrial lineages of the Southern Ocean crinoid species Promachocrinus kerguelensis (Echinodermata). Molecular Ecology, 21, 2502-2518.

Herrero-Pérezrul, M.D., Reyes-Bonilla, H., GarcíaDomínguez, F., \& Cintra-Buenrostro, C.E. (1999). Reproduction and growth of Isostichopus fuscus 
(Echinodermata: Holothuroidea) in the southern Gulf of California, México. Marine Biology, 135, 521-532.

Janies, D., Hernández-Díaz, Y.Q., Solís-Marín, F.A., Lopez, K., Alexandrov, B., Galac, M., Herrera, J., Cobb, J., Ebert, T.A., \& Bosch, I. (2019). Discovery of adults linked to cloning oceanic starfish larvae (Oreaster, Asteroidea: Echinodermata). Biological Bulletin, 236(3), 174-185.

Johnson K.B., \& Shanks, A.L. (2003). Low rates of predation on planktonic marine invertebrate larvae. Marine Ecology Progress Series, 248, 125-139.

Keesing, J.K., Halford, A.R., \& Hall, K.C. (2018). Mortality rates of small juvenile crown-of-thorns starfish Acanthaster planci on the Great Barrier Reef: implications for population size and larval settlement thresholds for outbreaks. Marine Ecology Progress Series, 597, 179-190.

Keever, C.C., Sunday, J., Puritz, J.B., Addison, J.A., Toonen, R.J., Grosberg, R.K., \& Hart, M. W. (2009). Discordant distribution of populations and genetic variation in a sea star with high dispersal potential. Evolution, 63(12), 3214-3227.

Lamare, M.D. \& Barker, M.F. (1999). In situ estimates of larval development and mortality in the New Zealand sea urchin Evechinus chloroticus (Echinodermata: Echinoidea). Marine Ecology Progress Series, 180, 197-211.

Levin, L.A. (2006). Recent progress in understanding larval dispersal: new directions and digressions. Integrative and Comparative Biology, 46(3), 282-297.

Marcus, N.H. (1977). Genetic variation within and between geographically separated populations of the sea urchin, Arbacia punctulata. Biological Bulletin, 153(3), 560-576.

Miller, K.M., Supernault, K.J., Li, S., \& Withler, R.E. (2006). Population structure in two marine invertebrate species (Panopea abrupta and Strongylocentrotus franciscanus) targeted for aquaculture and enhancement in British Columbia. Journal of Shellfish Research, 25(1), 33-42.

Moore, H.B. (1935). A comparison of the biology of Echinus esculentus in different habitats. Part II. Journal of the Marine Biological Association of the United Kingdom, 20, 109-128.

Muscat, A.M. (1975). Reproduction and growth in the ophiuroid, Ophionereis annulata (Master's thesis). San Diego State University, San Diego, California, USA.

Nichols, D., Sime, A.A.T., \& Bishop, G.M. (1985). Growth in populations of the sea-urchin Echinus esculentus L. (Echinodermata: Echinoidea) from the English Channel and Firth of Clyde. Journal of Experimental Marine Biology and Ecology, 86(3), 219-228.
Olguín-Espinoza, I. (2003). Speciation in marine systems: the case study of the sea urchin Arbacia incisa (Agassiz 1863) (Doctoral thesis) University of California Davis and San Diego State University, California, USA.

Olivares-Bañuelos, N.C, Enríquez-Paredes, L.M., Ladah, L.B., De La Rosa-Vélez, J. (2008) Population structure of purple sea urchin Strongylocentrotus purpuratus along the Baja California peninsula. Fisheries Science, 74, 804-812.

Ouréns, R., Flores, L., Fernández, L., \& Freire, J. (2013). Habitat and density-dependent growth of the sea urchin Paracentrotus lividus in Galicia (NW Spain). Journal of Sea Research, 76, 50-60.

Pineda, J., Hare, J.A., \& Sponaugle, S. (2007). Larval transport and dispersal in the coastal ocean and consequences for population connectivity. Oceanography, 20(3), 22-39.

Pirog, A., Gélin, P., Bédier, A., Bianchetti, G., Georget, S., Frouin, P., \& Magalon, H. (2017). Clonal structure through space and time: High stability in the holothurian Stichopus chloronotus (Echinodermata). Ecology and Evolution, 7(18), 7534-7547.

Powell, D.G. (1979). Estimation of mortality and growth parameters from the length frequency of a catch. Rapports et Procès-verbaux des Réunions, Conseil international pour L'Exploration de la Mer, 175, 167-169.

Quiroga, E., \& Sellanes, J. (2009). Growth and sizestructure of Stegophiura sp. (Echinodermata: Ophiuroidea) on the continental slope off central Chile: a comparison between cold seep and non-seep sites. Journal of the Marine Biological Association of the United Kingdom, 89(2), 421-428.

Rowley, R.J. (1990). Newly settled sea urchins in a kelp bed and urchin barren ground: a comparison of growth and mortality. Marine Ecology Progress Series, 62, 229-240.

Rumrill, S.S. (1987). Differential predation upon embryos and larvae of temperate Pacific echinoderms (Doctoral thesis). University of Alberta, Edmonton, Alberta, Canada.

Rumrill, S.S. (1990). Natural mortality of marine invertebrate larvae. Ophelia, 32, 163-198.

Schwamborn, R. (2018). How reliable are the PowellWetherall plot method and the maximum-length approach? Implications for length-based studies of growth and mortality. Reviews in Fish Biology and Fisheries, 28(3), 587-605.

Shelton, A.O., Woodby, D.A., Hebert, K., \& Witman, J.D. (2006). Evaluating age determination and spatial patterns of growth of the red sea urchins in southeast Alaska. Transactions of the American Fisheries Society, 135, 1670-1680. 
Soliman, T., Takama, O., Fernandez-Silva, I., \& Reimer, J.D. (2016). Extremely low genetic variability within and among locations of the greenfish holothuria Stichopus chloronotus Brandt, 1835 in Okinawa, Japan. PeerJ, 4, e2410.

Sun, J., Hamel, J.F., Gianasi, B.L., \& Mercier, A. (2019). Age determination in echinoderms: first evidence of annual growth rings in holothuroids. Proceedings of the Royal Society B, 286, 20190858.

Thorrold, S.R., Jones, G.P., Hallberg, M.E., Burton, R.S., Swearer, S.E., Neigel, J.E., Morgan, S.G., \& Warner, R.R. (2002). Quantifying larval retention and connectivity in marine populations with artificial and natural markers. Bulletin of Marine Science, 70(1), 291-308.

Thorson, G. (1961). Length of pelagic larval life in marine bottom invertebrates as related to larval transport by ocean currents. Oceanography AAAS Publication, $67,455-474$.

Uthicke, S., \& Benzie, J.A.H. (2003). Gene flow and population history in high dispersal marine invertebrates: mitochondrial DNA analysis of Holothuria nobilis (Echinodermata: Holothuroidea) populations from the Indo-Pacific. Molecular Ecology, 12(10), 2635-2648.

Uthicke, S., Benzie, J.A.H., \& Ballment, E. (1999). Population genetics of the fissiparous holothurian Stichopus chloronotus (Aspidochirotida) on the Great Barrier Reef, Australia. Coral Reefs, 18, 123-132.
Van Sickle, J. (1977). Mortality rates from size distributions. The application of a conservation law. Oecologia, 27, 311-318

Vaupel, J.W., Baudisch, A., Dölling, M., Roach, D.A., \& Gampe, J. (2004). The case for negative senescence. Theoretical Population Biology, 65(4), 339-351.

Vermeij, G.J., \& Grosberg, R.K. (2018). Rarity and persistence. Ecology Letters, 21, 3-8.

Watts, R.J., Johnson, M.S., \& Black, R. (1990). Effects of recruitment on genetic patchiness in the urchin Echinometra mathaei in Western Australia. Marine Biology, 105, 145-151.

Wetherall, J.A. (1986). A new method for estimating growth and mortality parameters from length-frequency data. Fishbyte, 4(1), 12-14.

White, J.W., Standish, J.D., Thorrold, S.R., \& Warner, R.R. (2008). Markov chain Monte Carlo methods for assigning larvae to natal sites using natural geochemical tags. Ecological Applications, 18(8), 1901-1913.

Wing, S.R., Gibbs, M.T., \& Lamare, M. D. (2003). Reproductive sources and sinks within a sea urchin, Evechinus chloroticus, population of a New Zealand fjord. Marine Ecology Progress Series, 248, 109-123.

Yasuda, N., Taquet, C., Nagai, S., Fortes, M., Suharsono, Adi Susanto, H., Phongsuwan, N., \& Nadaoka, K. (2012). Genetic structure of Culcita sp. pincushion seastar in the Coral Triangle. Cairns, Australia: Proceedings of the 12th International Coral Reef Symposium, 9-13 July 2012. 